\title{
Comparison of soil greenhouse gas fluxes from extensive and intensive grazing in a temperate maritime climate
}

\author{
U. Skiba ${ }^{1}$, S. K. Jones ${ }^{1,2}$, J. Drewer ${ }^{1}$, C. Helfter ${ }^{1}$, M. Anderson ${ }^{1}$, K. Dinsmore ${ }^{1}$, R. McKenzie ${ }^{1}$, E. Nemitz ${ }^{1}$, and \\ M. A. Sutton ${ }^{1}$ \\ ${ }^{1}$ Centre for Ecology and Hydrology, Bush Estate, Penicuik, Midlothian EH26 0QB, UK \\ ${ }^{2}$ Scotland's Rural College, West Mains Road, Edinburgh EH9 3JG, UK
}

Correspondence to: U. Skiba (ums@ceh.ac.uk)

Received: 5 July 2012 - Published in Biogeosciences Discuss.: 2 August 2012

Revised: 14 January 2013 - Accepted: 17 January 2013 - Published: 26 February 2013

\begin{abstract}
Greenhouse gas (GHG) fluxes from a seminatural, extensively sheep-grazed drained moorland and intensively sheep-grazed fertilised grassland in South East (SE) Scotland were compared over 4 yr (2007-2010). Nitrous oxide $\left(\mathrm{N}_{2} \mathrm{O}\right)$ and methane $\left(\mathrm{CH}_{4}\right)$ fluxes were measured by static chambers, respiration from soil plus ground vegetation by a flow-through chamber, and the net ecosystem exchange (NEE) of carbon dioxide $\left(\mathrm{CO}_{2}\right)$ by eddy-covariance. All GHG fluxes displayed high temporal and interannual variability. Temperature, radiation, water table height and precipitation could explain a significant percentage of seasonal and interannual variations. Greenhouse gas fluxes were dominated by the net ecosystem exchange of $\mathrm{CO}_{2}$ at both sites. Net ecosystem exchange of $\mathrm{CO}_{2}$ and respiration was much larger on the productive fertilised grassland $(-1567$ and $7157 \mathrm{~g} \mathrm{CO}_{2_{\mathrm{eq}}} \mathrm{m}^{-2} \mathrm{yr}^{-1}$, respectively) than on the seminatural moorland ( -267 and $2554 \mathrm{~g} \mathrm{CO}_{2 \mathrm{eq}} \mathrm{m}^{-2} \mathrm{yr}^{-1}$, respectively). Large ruminant $\mathrm{CH}_{4}\left(147 \mathrm{~g} \mathrm{CO}_{2 \mathrm{eq}} \mathrm{m}^{-2} \mathrm{yr}^{-1}\right)$ and soil $\mathrm{N}_{2} \mathrm{O}\left(384 \mathrm{~g} \mathrm{CO}_{2 \mathrm{eq}} \mathrm{m}^{-2} \mathrm{yr}^{-1}\right)$ losses from the grazed grassland counteracted the $\mathrm{CO}_{2}$ uptake by $34 \%$, whereas the small $\mathrm{N}_{2} \mathrm{O}\left(0.8 \mathrm{~g} \mathrm{CO}_{2_{\mathrm{eq}}} \mathrm{m}^{-2} \mathrm{yr}^{-1}\right)$ and $\mathrm{CH}_{4}\left(7 \mathrm{~g} \mathrm{CO}_{2_{\mathrm{eq}}} \mathrm{m}^{-2} \mathrm{yr}^{-1}\right)$ emissions from the moorland only impacted the NEE flux by $3 \%$. The 4-yr average GHG budget for the grazed grassland was $-1034 \mathrm{~g} \mathrm{CO}_{2_{\mathrm{eq}}} \mathrm{m}^{-2} \mathrm{yr}^{-1}$ and $-260 \mathrm{~g} \mathrm{CO}_{2_{\mathrm{eq}}} \mathrm{m}^{-2} \mathrm{yr}^{-1}$ for the moorland.
\end{abstract}

\section{Introduction}

European governments are required to reduce their greenhouse gas (GHG) emissions by $80 \%$ by 2050. Anthropogenic emissions are recorded annually through UNFCCC (United Nations Framework Convention on Climate Change) and CORINAIR (Core Inventory of Air Emissions in Europe) activities. This is done mostly by simple, but crude, IPCC Tier 1 emission factor approaches, which cannot accurately reflect regional variability and monitor mitigation. To improve the current reporting structure, countries have started to (i) develop and implement more complex Tier 2 reporting systems for some of the emission sectors and (ii) monitor GHG concentrations and fluxes at the landscapescale together with improving top-down modelling. Successful Tier 2 emission factors need to focus on easily measurable or documented variables (i.e. rainfall, temperature), and landscape scale measurements/top-down models would benefit from including emissions from seminatural/natural ecosystems. This paper addresses these requirements by comparing $4 \mathrm{yr}$ of GHG flux measurements from nearby intensively grazed grassland and extensively grazed moorland in a temperate maritime climate and assesses the drivers responsible for spatial and temporal variability. 


\section{Methods}

\subsection{Site description}

Auchencorth Moss (AMo) is a low-lying acid moorland ( $\mathrm{pH} 4.3$, in $\mathrm{H}_{2} \mathrm{O}$ ) dominated by grasses and is approximately $17 \mathrm{~km}$ south-west (SW) of Edinburgh, Scotland (Table 1) (Drewer et al., 2010). The moorland, which is not fertilised, was drained about $100 \mathrm{yr}$ ago and again in the 1960 s to improve the land for extensive grazing. The peat depth is now mostly $0.5 \mathrm{~m}$, but in places up to $2 \mathrm{~m}$ deep. The moss is extensively grazed by sheep at a very low stocking density of $<0.2 \mathrm{LSU} \mathrm{ha}^{-1}$, which equates to circa $1 \mathrm{ewe} \mathrm{ha}^{-1}$, accompanied by one to two lambs between April and September $(1 \mathrm{LSU}$ (livestock unit) $=1$ animal of $600 \mathrm{~kg}$ live weight, therefore $1 \mathrm{ewe}=0.1 \mathrm{LSU}$ and $1 \mathrm{lamb}=0.04 \mathrm{LSU}$ ).

In contrast, two adjacent fields at Easter Bush (EBu), $7 \mathrm{~km}$ north-west (NW) of AMo, have been intensively managed for livestock grazing for over $20 \mathrm{yr}$. The grass is grown on an imperfectly drained Macmerry soil of the Rowanhill soil association (eutric cambisol, FAO classification) with a $\mathrm{pH}$ (in $\mathrm{H}_{2} \mathrm{O}$ ) of 5.1 and a clay fraction of $20 \%$ to $26 \%$ (Table 1). Although the fields were drained over $50 \mathrm{yr}$ ago, the drainage system no longer operates properly and large puddles of standing water are a regular occurrence during prolonged periods of rain. The fields have not been ploughed in the last $20 \mathrm{yr}$, and were only cut on three occasions once in 2002, 2003 and 2004. Grazing occurs all year round, and animals always have access to the entire field, but livestock is occasionally taken off the field for periods of one day to several weeks. Annual livestock numbers were calculated from farmers and our own records. Between 2002 and 2006 the average stocking density was $0.7 \mathrm{LSU} \mathrm{ha}^{-1}$, and consisted of beef cattle (30\%) and ewes + lambs (70\%). Lambs are only present between April and September. To maintain the high stocking densities, the grassland received predominately granules of mineral $\mathrm{N}$ fertiliser, either as ammonium nitrate or a NPK compound fertiliser between March and August. The average annual $\mathrm{N}$ fertilisation rate between 2002 and 2010 was $245 \mathrm{~kg} \mathrm{Nha}^{-1} \mathrm{yr}^{-1}$. Since 2002 cattle slurry was only applied in September $2004\left(69 \mathrm{~kg} \mathrm{~N} \mathrm{ha}^{-1} \mathrm{yr}^{-1}\right)$ and March 2005 (158 kg N ha $\left.{ }^{-1} \mathrm{yr}^{-1}\right)$.

During the 2007 to 2010 study period, fields were only stocked with sheep at an average annual stocking density of $0.77 \mathrm{LSU} \mathrm{ha}^{-1}$ (Table 1). Animal numbers ranged from 0 to 170 ewes ( 0 to $17 \mathrm{LSU} \mathrm{ha}^{-1}$ ) and 0 to 260 lambs $(0$ to $10 \mathrm{LSU} \mathrm{ha}^{-1}$ ). Between spring 2007 and summer 2010, $\mathrm{N}$ fertiliser was applied on 16 occasions. The average application rate was 58 (range 35 to 92 ) $\mathrm{kg} \mathrm{N} \mathrm{ha}^{-1}$. There were three applications in 2007 and 2010, four in 2009 and six in 2008 (Table 1). Mostly ammonium nitrate was applied, but on three occasions (August 2008, March and May 2009) urea was used and once a NPK compound fertiliser (June 2009).

Both sites are long-term field sites run by the Centre for Ecology and Hydrology (CEH), where we have studied car- bon and nitrogen fluxes and pools as part of a range of national and European programmes, including Graminae (Sutton et al., 2001), GreenGrass (Soussana et al., 2007), NitroEurope (Skiba et al., 2009) and CarboEurope (Schulze et al., 2010).

\subsection{Soil greenhouse gas flux measurements}

Methane and nitrous oxide fluxes were measured by static chambers. Chambers were manufactured from opaque polypropylene pipes $(0.4 \mathrm{~m}$ in diameter) cut to lengths of $0.2 \mathrm{~m}$ and fitted with a 0.05 -m-wide flange at the outward facing end (Clayton et al., 1994). The pipe was inserted into the soil at approx. 0.03 to $0.07 \mathrm{~m}$ depth, and the chamber volume was approximately $17 \mathrm{~L}$. The measurement protocol was slightly different at the two sites.

At AMo, nine chambers were installed within a $25 \mathrm{~m}$ radius of each other and within the main fetch of the $\mathrm{CO}_{2}$ eddycovariance tower. They remained in position over the 4-yr study period and covered the most dominant vegetation types on the Moss: three chambers each on (1) hummocks dominated by Deschampsia and/or Eriophorum, (2) hummocks of Juncus and (3) hollows dominated by mosses. To measure fluxes a flexible, transparent, dome-shaped polyethylene lid was placed onto the chamber for approximately $60 \mathrm{~min}$ (MacDonald et al., 1996). Air samples $(200 \mathrm{~mL}$ ) were withdrawn via a three-way tap fitted at the side of the chamber, just after chamber closure and then approximately 30 and $60 \mathrm{~min}$ later (later referred to as $t_{0}, t_{30}, t_{60}$ ). To mix the chamber air, the syringe was flushed three times before collection into $500 \mathrm{~mL}$ Tedlar ${ }^{\circledR}$ bags. During summer it was necessary to fit extension collars onto chambers containing Juncus; as a result, the volume of air enclosed in each chamber was then approx. $30 \mathrm{~L}$. Measuring the volume of a chamber enclosing hummock vegetation was not easy due to uneven hummock shapes and hidden airspaces within the hummock. Instead of just measuring the chamber height, as done at $\mathrm{EBu}$, we filled the chambers with a known $\mathrm{SF}_{6}$ concentration (4.8 ppb), stirred the air by fan and collected chamber air after $5 \mathrm{~min}$ incubation. The volume was calculated from the magnitude of dilution of $\mathrm{SF}_{6}$ (Dinsmore, 2008).

At $\mathrm{EBu}$, eight chambers were inserted: four within the eddy-covariance footprint of the prevailing SW wind direction and another four in the NW direction (Jones et al., 2011). Chambers were moved every fortnight to allow free grazing. For flux measurements chambers were sealed with aluminium lids fitted with a central port for sample collection. At the beginning of the incubation period, ambient air samples were taken from about $0.5 \mathrm{~m}$ above the soil surface next to the chambers $\left(t_{0}\right)$. After about $60 \mathrm{~min}$ incubation $\left(t_{60}\right), 200 \mathrm{~mL}$ samples were withdrawn from inside the chambers into Tedlar ${ }^{\circledR}$ bags. Linearity tests, taking samples every $15 \mathrm{~min}$ over $2 \mathrm{~h}$, were carried out several times during the study period and demonstrated linearity of up to $120 \mathrm{~min}$ with an average $r^{2}=0.96$ for $\mathrm{N}_{2} \mathrm{O}$. 
Table 1. Site characteristics and climate data for Auchencorth Moss and Easter Bush.

\begin{tabular}{|c|c|c|}
\hline Parameter & Easter Bush & Auchencorth Moss \\
\hline Latitude/Longitude & 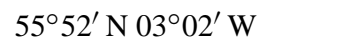 & $55^{\circ} 47^{\prime} \mathrm{N} 03^{\circ} 14^{\prime} \mathrm{W}$ \\
\hline Ecosystem type & Managed grazed grassland & Drained peatland \\
\hline Vegetation & $99 \%$ Lolium perenne & $\begin{array}{l}\text { Deschampsia flexuosa, } \\
\text { Molinia caerulea, } \\
\text { Festuca ovina, } \\
\text { Eriophorum angustifolium, } \\
\text { Eriophorum vaginatum, } \\
\text { Juncus effusus, } \\
\text { Juncus squarrosus, } \\
\text { Calluna vulgaris; } \\
\text { bryophytes are dominated by Sphagnum } \\
\text { and Polytrichum species }\end{array}$ \\
\hline Soil type & Clay loam & Peat $\sim 0.5-2 \mathrm{~m}$ deep \\
\hline \multicolumn{3}{|c|}{ Livestock (LSU ha $\left.{ }^{-1}\right)^{\mathrm{a}}$} \\
\hline 2007 & 0.91 & $<0.2$ \\
\hline 2008 & 0.82 & $<0.2$ \\
\hline 2009 & 0.72 & $<0.2$ \\
\hline 2010 & 0.63 & $<0.2$ \\
\hline \multicolumn{3}{|c|}{$\mathrm{N}$ fertiliser $\left(\mathrm{kg} \mathrm{N} \mathrm{ha}^{-1} \mathrm{y}^{-1}\right)^{\mathrm{b}}$} \\
\hline 2007 & 173 & 0 \\
\hline 2008 & 311 & 0 \\
\hline 2009 & 250 & 0 \\
\hline 2010 & 190 & 0 \\
\hline \multicolumn{3}{|c|}{ Cumulative precipitation $(\mathrm{mm})^{\mathrm{c}}$} \\
\hline 2007 & $1015(498 ; 517)$ & $1127(550 ; 577)$ \\
\hline 2008 & $1065(514 ; 551)$ & $1212(658 ; 554)$ \\
\hline 2009 & $744(295 ; 449)$ & $987(446 ; 541)$ \\
\hline 2010 & $927(565 ; 362)$ & $1072(561 ; 511)$ \\
\hline \multicolumn{3}{|c|}{ Air temperature $\left({ }^{\circ} \mathrm{C}\right)^{\mathrm{d}}$} \\
\hline 2007 & $9.1(6.7,11.7)$ & $8.0(5.2 ; 10.4)$ \\
\hline 2008 & $8.6(5.3 ; 11.8)$ & $7.3(3.9 ; 10.3)$ \\
\hline 2009 & $8.9(5.5 ; 12.3)$ & $7.6(4.0 ; 10.7)$ \\
\hline 2010 & $7.7(4.3 ; 11.9)$ & $6.6(3.0 ; 10.8)$ \\
\hline
\end{tabular}

${ }^{\text {a }}$ Livestock unit ha ${ }^{-1}=10$ adult sheep or 25 lambs,

$\mathrm{b}$ annual total,

c annual total (total for January-March + October-December; April-September, i.e. cold; warm period),

$\mathrm{d}$ annual average (average for January-March + October-December; April-September).

Samples were analysed for $\mathrm{N}_{2} \mathrm{O}$ and $\mathrm{CH}_{4}$ within one week of collection. In the laboratory, samples were transferred to glass vials and were analyzed using a Hewlett Packard 5890 series II gas chromatograph (Agilent Technologies, Stockport, UK), fitted with an electron capture detector for $\mathrm{N}_{2} \mathrm{O}$ and a flame ionisation detector for $\mathrm{CH}_{4}$. Fluxes were calculated from the difference of gas concentration from the start $\left(t_{0}\right)$ and average concentration increase at $t_{30}$ and $t_{60}$ for AMo samples and the concentration increase at $t_{60}$ for EBu samples. Concentration differences were converted to gas densities assuming standard temperature and pressure conditions, multiplied by the chamber volume and divided by the chamber area and time of incubation. The minimum detectable flux was $3 \mu \mathrm{g} \mathrm{N}_{2} \mathrm{O} \mathrm{m}^{-2} \mathrm{~h}^{-1}$ and $6 \mu \mathrm{g} \mathrm{CH}_{4} \mathrm{~m}^{-2} \mathrm{~h}^{-1}$.
Respiration from soil including the ground-covering vegetation (grass at EBu and mosses and small herbs at AMo) was measured close to all static chambers at AMo and EBu using a PP-Systems (Hitchin, UK) SCR-1 respiration chamber (0.1 m diameter) attached to an EGM-4 infrared gas analyser (Dinsmore et al., 2009). The chamber was placed onto the ground for 1-2 min periods, during which chamber air was re-circulated between chamber and EGM-4. Fluxes were calculated from the linear increase in concentration, taking into account the soil temperature at the time of measurement. The ground at AMo was too soft to create a proper seal between soil and chamber. Therefore, during measurements the chamber was attached to small plastic collars which were inserted $0.05 \mathrm{~m}$ into the peat before the start of the 4-yr study period. 
Measurements were usually made when $\mathrm{N}_{2} \mathrm{O}$ and $\mathrm{CH}_{4}$ fluxes were measured.

The frequency of soil GHG flux measurements was different at the two locations. At EBu, outwith fertilisation periods, fluxes were measured weekly during the growing period and fortnightly in winter. Intensive measurements scaling down from daily to weekly were made immediately after $\mathrm{N}$ fertiliser applications. Between January 2007 and December 2010, we measured $\mathrm{N}_{2} \mathrm{O}, \mathrm{CH}_{4}$ and respiration on 248, 239 and 222 dates, respectively. At AMo, fluxes were measured approximately every two weeks during the growing season and every four weeks in winter, in total on $78\left(\mathrm{~N}_{2} \mathrm{O}\right.$ and $\mathrm{CH}_{4}$ ) and 49 (respiration) dates.

\subsection{Net ecosystem exchange of carbon dioxide}

The net ecosystem exchange (NEE) of $\mathrm{CO}_{2}$ was measured by eddy-covariance at both locations, using a fast-response closed-path $\mathrm{CO}_{2}$ and $\mathrm{H}_{2} \mathrm{O}$ analyser (Li-COR 7000 IRGA, LI-COR Lincoln, USA) operating at $10 \mathrm{~Hz}$ and an ultrasonic anemometer (Gill WindMaster Pro, Lymington, UK) operating at $20 \mathrm{~Hz}$. The sample inlet was fixed just below the ultrasonic anemometer at a height of $3.6 \mathrm{~m}$ at AMo and at $2.5 \mathrm{~m}$ at $\mathrm{EBu}$. The LI-COR instruments were situated in mains-powered research cabins $20 \mathrm{~m}(\mathrm{Amo})$ and $10 \mathrm{~m}(\mathrm{EBu})$ away from the towers. Air samples were drawn into the analysers via $6 \mathrm{~mm}$ (out-diameter) non-reactive tubing. The three-dimensional wind vector components, sonic temperature, $\mathrm{CO}_{2}$ and $\mathrm{H}_{2} \mathrm{O}$ concentrations were logged using an inhouse $\mathrm{LabView}^{\mathrm{TM}}$ data acquisition program. The data were filtered offline. The following data were excluded from the analysis: $\mathrm{CO}_{2}$ molar fractions not in the range of $350 \mathrm{ppm}$ to $500 \mathrm{ppm}$, and hourly data (a) with standard deviations of mean vertical wind velocities $>1 \mathrm{~m} \mathrm{~s}^{-1}$, (b) with total sample numbers $<30000$ and (c) not meeting the criteria of the stationarity test described in Foken and Wichura (1996) and, Foken et al. (2004). Data during periods of low turbulence $\left(<0.2 \mathrm{~m} \mathrm{~s}^{-1}\right)$, unrepresentative wind directions and malfunctions of the analysers were filtered out. The annual data coverage, expressed as a percentage of total annual hourly data before filtering, ranged from $76 \%$ to $85 \%$ and after filtering from $57 \%$ to $77 \%$. Eddy-covariance $\mathrm{CO}_{2}$ fluxes were calculated following CarboEurope protocols (Reichstein et al., 2005). The protocols prescribed how to deal with block averaging, coordinate rotation, lag-time calculation, density corrections and corrections for the systematic high-frequency loss. Gaps were filled using the online tool developed by M. Reichstein (http://www.bgc-jena.mpg.de/ $\sim$ MDIwork/eddyproc/upload.php), and $\mathrm{CO}_{2}$ fluxes were calculated for 30 min periods.

\subsection{Environmental measurements}

Both study locations were supersites in the NitroEurope project, which means that fluxes and pools of carbon and ni-
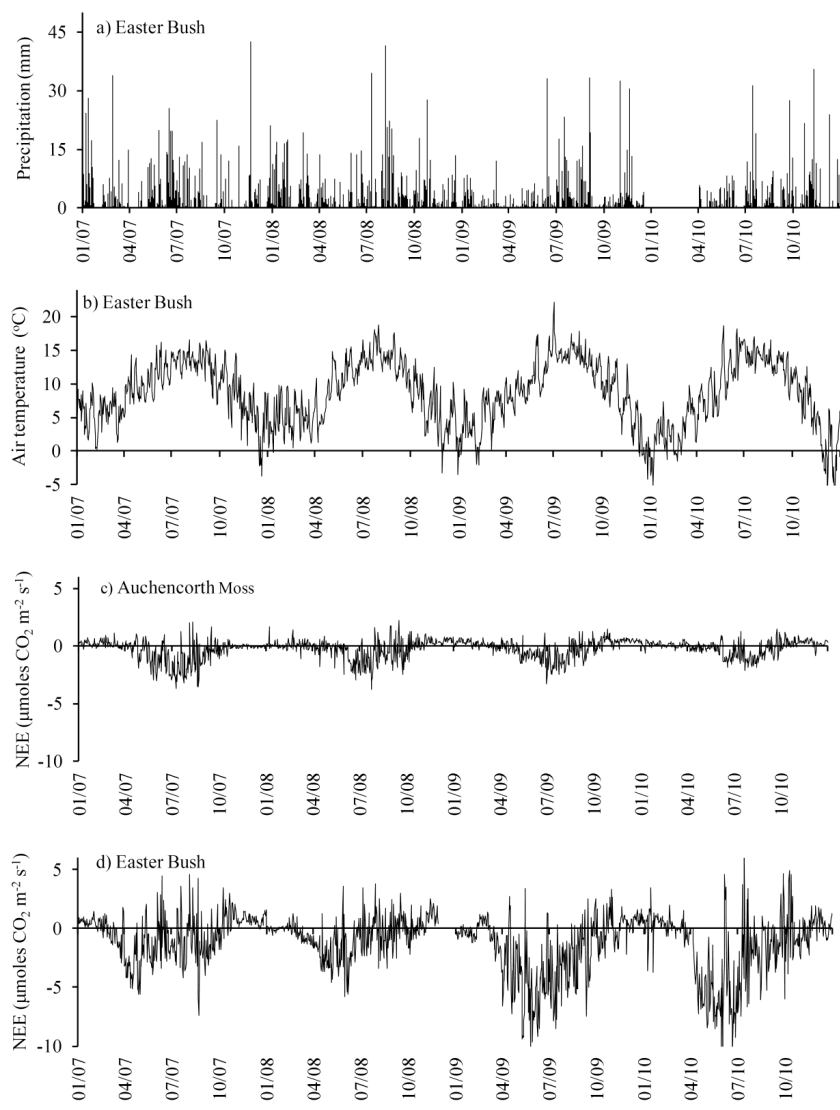

Fig. 1. Daily average air temperature (a) and daily cumulative precipitation at Easter Bush (b). Counterpart data for Auchencorth Moss are not shown as the pattern is almost identical. Daily net ecosystem exchange of $\mathrm{CO}_{2}$ (NEE) calculated from $30 \mathrm{~min}$ averages at Auchencorth Moss (c) and Easter Bush (d).

trogen compounds and meteorological data were measured intensively following a common measurement protocol outlined in Skiba et al. (2009). The measured parameters that caused significant influence on the GHG fluxes discussed in this paper were air temperature, soil temperature, soil heat flux, total solar radiation, photosynthetically active radiation (PAR), net radiation, rainfall, soil moisture and water table height. Average air temperature and cumulative rainfall (using a tipping bucket) were recorded every $30 \mathrm{~min}$ from the meteorological stations at both sites. The volumetric soil moisture content at $0.1 \mathrm{~m}$ depth was measured using a Theta probe (Delta-T Devices Ltd., Cambridge, UK). In addition water table height was recorded from dip wells $(0.04 \mathrm{~m}$ diameter) inserted adjacent to each flux chamber at AMo. The moisture and water table measurements were made whenever $\mathrm{N}_{2} \mathrm{O}$ and $\mathrm{CH}_{4}$ fluxes were measured. 
Table 2. Annual soil greenhouse gas (GHG) and NEE fluxes $\left(\mathrm{g} \mathrm{CO}_{2 \mathrm{eq}} \mathrm{m}^{-2} \mathrm{yr}^{-1}\right)$ from the intensively grazed grassland "Easter Bush" and the extensively grazed moorland "Auchencorth Moss".

\begin{tabular}{|c|c|c|c|c|c|c|}
\hline \multirow[t]{2}{*}{ GHG \& year } & \multicolumn{3}{|c|}{ Easter Bush } & \multicolumn{3}{|c|}{ Auchencorth Moss } \\
\hline & Average $^{\mathrm{a}}$ & Stdev $^{b}$ & $N^{\mathrm{c}}$ & Average $^{\mathrm{a}}$ & Stdev $^{b}$ & $N^{\mathrm{c}}$ \\
\hline \multicolumn{7}{|l|}{$\mathrm{N}_{2} \mathrm{O}$} \\
\hline 2007 & 660 & 564 & 66 & 0.3 & 1.3 & 24 \\
\hline 2008 & 532 & 492 & 83 & 9.1 & 17.3 & 21 \\
\hline 2009 & 208 & 219 & 60 & -0.3 & 12.1 & 21 \\
\hline 2010 & 137 & 155 & 39 & -6.0 & 16.9 & 12 \\
\hline \multicolumn{7}{|l|}{$\mathrm{CH}_{4}$ soil } \\
\hline 2007 & 1.6 & 5.2 & 66 & 9.4 & 1.4 & 24 \\
\hline 2008 & 0.3 & 3.9 & 77 & 10.8 & 17.0 & 21 \\
\hline 2009 & 1.0 & 5.6 & 57 & 6.9 & 9.5 & 21 \\
\hline 2010 & 3.0 & 4.9 & 39 & -0.5 & 2.8 & 12 \\
\hline \multicolumn{7}{|l|}{$\mathrm{CH}_{4}$ livestock } \\
\hline 2007 & 174 & & & $0^{\mathrm{d}}$ & & \\
\hline 2008 & 161 & & & 0 & & \\
\hline 2009 & 135 & & & 0 & & \\
\hline 2010 & 119 & & & 0 & & \\
\hline \multicolumn{7}{|c|}{$\mathrm{CO}_{2}$ respiration $^{\mathrm{e}}$} \\
\hline 2007 & 6432 & 2099 & 61 & 2395 & 1582 & 10 \\
\hline 2008 & 7030 & 2244 & 72 & 2660 & 6909 & 13 \\
\hline 2009 & 8044 & 1946 & 52 & 2755 & 11137 & 16 \\
\hline 2010 & 7120 & 2532 & 37 & 2404 & 9335 & 10 \\
\hline \multicolumn{7}{|c|}{$\mathrm{CO}_{2}$ net ecosystem exchange } \\
\hline 2007 & -758 & & Gap- & -498 & Gap- & \\
\hline 2008 & -784 & & filled ${ }^{\mathrm{f}}$ & -300 & filled ${ }^{\mathrm{f}}$ & \\
\hline 2009 & -2462 & & & -145 & & \\
\hline 2010 & -2264 & & & -125 & & \\
\hline \multicolumn{7}{|l|}{ GHG budgets $\mathrm{g}$} \\
\hline 2007 & +78 & & & -488 & & \\
\hline 2008 & -91 & & & -280 & & \\
\hline 2009 & -2118 & & & -138 & & \\
\hline 2010 & -2005 & & & -131 & & \\
\hline
\end{tabular}

a Annual fluxes of soil GHG were calculated from monthly averages of eight chamber measurements at Easter Bush and nine chamber measurements at Auchencorth Moss.

${ }^{b}$ Standard deviation is the average variation across the chambers.

${ }^{c}$ Number of observations is the total number of measurement dates in each year.

$\mathrm{d}$ There are no records of actual sheep numbers; we assumed $<1$ ewe ha ${ }^{-1} ; \mathrm{CH}_{4}$ emissions are

$<0.004 \mathrm{~g} \mathrm{CO}_{2 \mathrm{eq}} \mathrm{m}^{-2} \mathrm{yr}^{-1}$.

${ }^{\mathrm{e}}$ Respiration from soil plus small vegetation enclosed by the chamber.

f Annual fluxes were calculated from gap-filled daily averages of $30 \mathrm{~min}$ data.

g GHG budgets for $\mathrm{EBu}$ included $\mathrm{CH}_{4}$ emissions from ruminant fermentation.

\subsection{Statistical methods}

Minitab version 16 was used to identify significant correlations between greenhouse gases and climate and soil variables.

\section{Results}

Rainfall and temperature patterns are very similar at both sites and therefore are only shown for EBu in Fig. 1a and b. AMo is on average $1.2^{\circ} \mathrm{C}$ colder than $\mathrm{EBu}$ and precipitation is $17 \%$ larger, although the inter-annual variability is larger than the differences between sites (Table 1). The driest year was 2009, with monthly rainfall in February, April and October less than $26 \mathrm{~mm}$ at EBu and in February and April less than $31 \mathrm{~mm}$ at AMo. In 2007 and 2008 very similar cumulative rainfall was measured between April and September (warm period) and January and March plus October and December (the cold period) at both sites. But in 2009 and 2010 cumulative warm period rainfall was 1.5 -fold larger than in the cold period at EBu. At AMo warm period rainfall was 1.2- and 2.1-fold larger in 2009 and 2010, respectively. Neither site receives a lot of snow; and snow accumulation $>50 \mathrm{~mm}$ is rare, except in 2010, when snow 
disrupted precipitation measurements from 1 January to the beginning of March 2010 followed by no precipitation until beginning of April. Snowfall was estimated from the ratio of precipitation and discharge, recorded at the small burn on AMo not far from the flux measurement site. The warm period average temperatures were almost the same for the $4 \mathrm{yr}$, $11.9 \pm 0.24^{\circ} \mathrm{C}$ at $\mathrm{EBu}$ and $10.5 \pm 0.24^{\circ} \mathrm{C}$ at AMo. However, cold period temperatures changed, with highest averages in 2007 (6.4 and 5.29 ${ }^{\circ} \mathrm{C}$ in 2007) and lowest in 2010 (4.3 and 2.9 at $\mathrm{EBu}$ and $\mathrm{AMo}$, respectively).

Average fluxes of $\mathrm{CO}_{2}$ respiration and NEE over the $4 \mathrm{yr}$ were three and six times larger at EBu than at AMo, respectively, and soil $\mathrm{CH}_{4}$ fluxes were five times smaller at $\mathrm{EBu}$ than at AMo. Nitrous oxide fluxes were around zero at AMo and two orders of magnitude larger at EBu (Table 2). Spatial variability between the nine flux chambers at AMo and the eight chambers at EBu was very high. Standard deviations calculated as a percentage of the flux for each measurement date at $\mathrm{AMo}$ and $\mathrm{EBu}$, respectively, were on average $7 \%$ and $31 \%$ for respiration, $62 \%$ and $121 \%$ for $\mathrm{N}_{2} \mathrm{O}$ and $372 \%$ and $372 \%$ for $\mathrm{CH}_{4}$ flux. Note that for $\mathrm{CH}_{4}$ the same high variability of $372 \%$ was measured at both sites. Temporal variations, which were also very large for $\mathrm{CH}_{4}, \mathrm{~N}_{2} \mathrm{O}$, NEE and ecosystem respiration are described in detail below.

\subsection{Methane fluxes}

At AMo $\mathrm{CH}_{4}$ fluxes ranged from -38 to $+604 \mu \mathrm{g} \mathrm{CH}_{4} \mathrm{~m}^{-2} \mathrm{~h}^{-1}$ between January 2007 and December 2010 and the average flux was $+37 \mu \mathrm{g} \mathrm{CH}_{4} \mathrm{~m}^{-2} \mathrm{~h}^{-1}$ (Fig. 2a). Methane fluxes correlated significantly with water table height $(p<0.05$, Fig. 3) and soil temperature at a depth of $0.4 \mathrm{~m}(p<0.05)$, but not with soil temperatures at 0.1 or $0.2 \mathrm{~m}$ depth, air temperature or cumulative precipitation that fell on the day and 6 days before flux measurements were made. $\mathrm{A}$ net $\mathrm{CH}_{4}$ uptake dominated when the water table was below $0.2 \mathrm{~m}$; then the average flux was $-8 \mu \mathrm{gCH}_{4} \mathrm{~m}^{-2} \mathrm{~h}^{-1}$ with a range from -38 to $+18 \mu \mathrm{g} \mathrm{CH}_{4} \mathrm{~m}^{-2} \mathrm{~h}^{-1}$. When the water table was closer to the surface $(<0.2 \mathrm{~m}$ depth $), \mathrm{CH}_{4}$ emissions prevailed; the average flux was $51 \mu \mathrm{g} \mathrm{CH}_{4} \mathrm{~m}^{-2} \mathrm{~h}^{-1}$ with a range of -6 to $+604 \mu \mathrm{g} \mathrm{CH} \mathrm{Cm}^{-2} \mathrm{~h}^{-1}$. Methane fluxes $>+100 \mu \mathrm{g} \mathrm{CH} \mathrm{CH}_{4} \mathrm{~m}^{-2} \mathrm{~h}^{-1}$ were only measured when the soil temperature at $0.4 \mathrm{~m}$ depth was at and above $10^{\circ} \mathrm{C}$, except on one occasion when at $5^{\circ} \mathrm{C}$ a flux of $+161 \mu \mathrm{CH}_{4} \mathrm{~m}^{-2} \mathrm{~h}^{-1}$ was measured.

At the grazed grassland $\mathrm{EBu}$, the average $\mathrm{CH}_{4}$ flux was 4.5 (range -44 to 113) $\mu \mathrm{g} \mathrm{m}^{-2} \mathrm{~h}^{-1}$ (Fig. 2b). On more than $50 \%$ of the measurement dates, fluxes were either negative or smaller than $5 \mu \mathrm{g} \mathrm{CH}_{4} \mathrm{~m}^{-2} \mathrm{~h}^{-1}$. Larger fluxes occurred sporadically, often only in one of the eight chambers. Monthly average $\mathrm{CH}_{4}$ fluxes correlated with the average daily soil heat flux $(p<0.05)$.
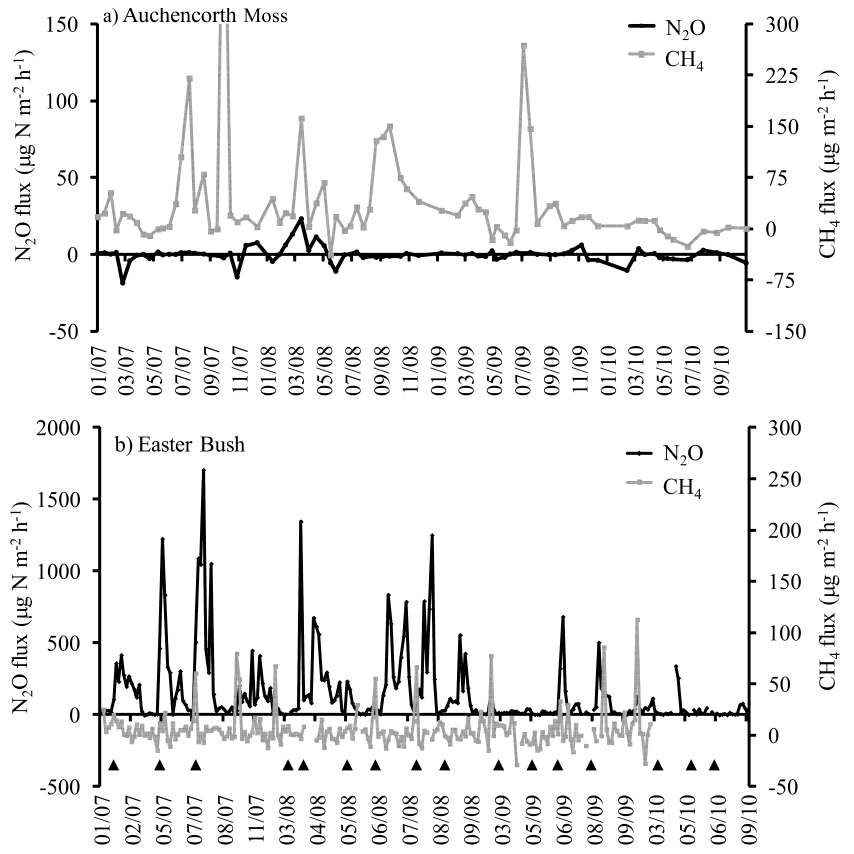

Fig. 2. Variations of $\mathrm{CH}_{4}$ and $\mathrm{N}_{2} \mathrm{O}$ fluxes from the unmanaged, extensively grazed moorland Auchencorth Moss (a) and the $\mathrm{N}$-fertilised, intensively grazed grassland Easter Bush (b). Data are averages from nine chamber measurements at Auchencorth Moss and eight at Easter Bush. Note the different scales for Auchencorth Moss and Easter Bush and for $\mathrm{N}_{2} \mathrm{O}$ and $\mathrm{CH}_{4}$. X-axes (mm/yy) are scaled by number of measurement, rather than date. Black triangles indicate when $\mathrm{N}$ fertiliser was applied at Easter Bush. The "off-scale" $\mathrm{CH}_{4}$ flux in October 2007 at Auchencorth Moss was $604 \mu \mathrm{g} \mathrm{CH} \mathrm{m}^{-2} \mathrm{~h}^{-1}$.

\subsection{Nitrous oxide fluxes}

At AMo, the average $\mathrm{N}_{2} \mathrm{O}$ flux was $-0.14 \mu \mathrm{g} \mathrm{N}_{2} \mathrm{O}$ $\mathrm{N} \mathrm{m}^{-2} \mathrm{~h}^{-1}$ (range -19 to $+23 \mu \mathrm{g} \mathrm{N}_{2} \mathrm{O}-\mathrm{N} \mathrm{m}^{-2} \mathrm{~h}^{-1}$ ) (Fig. 2a). Correlations between $\mathrm{N}_{2} \mathrm{O}$ flux and water table height, air and soil temperature, heat flux or precipitation were not statistically significant.

Over the 4-yr study period, $\mathrm{EBu} \mathrm{N}_{2} \mathrm{O}$ fluxes ranged from -5 to $1703 \mu \mathrm{g} \mathrm{N} \mathrm{N}_{2} \mathrm{O}-\mathrm{N} \mathrm{m}^{-2} \mathrm{~h}^{-1}$ (mean $146, n=248$ ). Mineral $\mathrm{N}$ fertiliser applications stimulated $\mathrm{N}_{2} \mathrm{O}$ emissions, and most of the large emission peaks seen in Fig. 2b were measured during the first 2 to 25 days after application. Sometimes the fertiliser response was immediate $(<1$ day, March, May and July 2007, April and May 2008, and June 2009), and on others there was a delay of 5 (June 2008), 9 (August 2008), 14 (March 2008) and 20 days (March 2010). The fertilisation events in March and May 2009, May and June 2010, did not stimulate measured $\mathrm{N}_{2} \mathrm{O}$ emissions significantly. To further investigate these differences, we divided the data set into two groups: (i) average fluxes over the three weeks after fertilisation and (ii) average threeweek fluxes for all other dates. $\mathrm{N}_{2} \mathrm{O}$ fluxes averaged over 


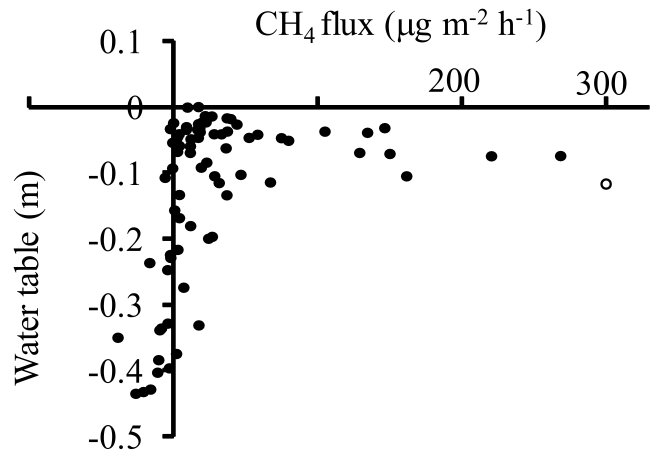

Fig. 3. The influence of water table height on $\mathrm{CH}_{4}$ fluxes at Auchencorth Moss observed between 2007 and 2010 (data are monthly averages). The "off-scale" $\mathrm{CH}_{4}$ flux in October 2007 was $604 \mu \mathrm{g} \mathrm{CH}_{4} \mathrm{~m}^{-2} \mathrm{~h}^{-1}$ and defined by an open circle.

the three-week period after fertilisation were much larger than fluxes averaged over three-week periods not affected by fertilisation (period (i): $205 \pm 195 \mu \mathrm{g} \mathrm{N}_{2} \mathrm{O}-\mathrm{N} \mathrm{m}^{-2} \mathrm{~h}^{-1}$, range 9.5 to $700, n=16$; period (ii): $51 \pm 65 \mu \mathrm{g} \mathrm{N}_{2} \mathrm{O}-\mathrm{N} \mathrm{m}^{-2} \mathrm{~h}^{-1}$, range -3.4 to $255, n=36$ ). In fertilisation periods (period (i)) $\mathrm{N}_{2} \mathrm{O}$ fluxes correlated with the total rainfall that fell within these three weeks. An improved significant correlation $(p<0.001)$ was obtained when the rainfall of the week prior fertilisation was added to the rainfall that fell in period (i) (Fig. 4). Due to different fertiliser application rates (35 to $\left.92 \mathrm{~kg} \mathrm{~N} \mathrm{ha}^{-1}\right), \mathrm{N}_{2} \mathrm{O}$ data in Fig. 4 were expressed as percentage of $\mathrm{N}$ applied. Smallest emission factors were calculated when the cumulative rainfall was $<55 \mathrm{~mm}$. This was the case for all fertilisation periods in 2010, March and May 2009 and May 2008 fertilisations (Fig. 4). In the three-week fertilisation period (i) $\mathrm{N}_{2} \mathrm{O}$ fluxes tended to increase with soil moisture and air temperature, but these trends were not significant. In three-week periods not affected by fertiliser (period ii), $\mathrm{N}_{2} \mathrm{O}$ fluxes did not correlate with the cumulative precipitation; however, there was a significant correlation with air temperature $(P<0.001)$.

\subsection{Soil and ground cover respiration of carbon dioxide}

Respiration measured at $\mathrm{AMo}$ and $\mathrm{EBu}$ is the sum of soil respiration and that from any vegetation enclosed by the flux chamber. AMo respiration rates ranged from 81 to $694 \mathrm{mg} \mathrm{CO}_{2} \mathrm{~m}^{-2} \mathrm{~h}^{-1}$ at $\mathrm{AMo}$ (average $285 \mathrm{mg} \mathrm{CO}_{2} \mathrm{~m}^{-2} \mathrm{~h}^{-1}$ ), but were around 3-fold larger at $\mathrm{EBu}$ (average $1003 \mathrm{mg} \mathrm{CO}_{2} \mathrm{~m}^{-2} \mathrm{~h}^{-1}$, range 98 to $\left.3126 \mathrm{mg} \mathrm{CO}_{2} \mathrm{~m}^{-2} \mathrm{~h}^{-1}\right)$. At both sites monthly ground respiration rates correlated significantly $(p<0.001)$ with air temperature, total solar radiation, net radiation, PAR and NEE (Fig. 5) and with soil heat flux $(p<0.01)$. At AMo, respiration also increased significantly $(p<0.001)$ with increasing daily average soil temperature measured at 10,20 and $40 \mathrm{~cm}$ depth and decreased significantly $(p<0.001)$ with increasing daily average water table height. At EBu respiration rates

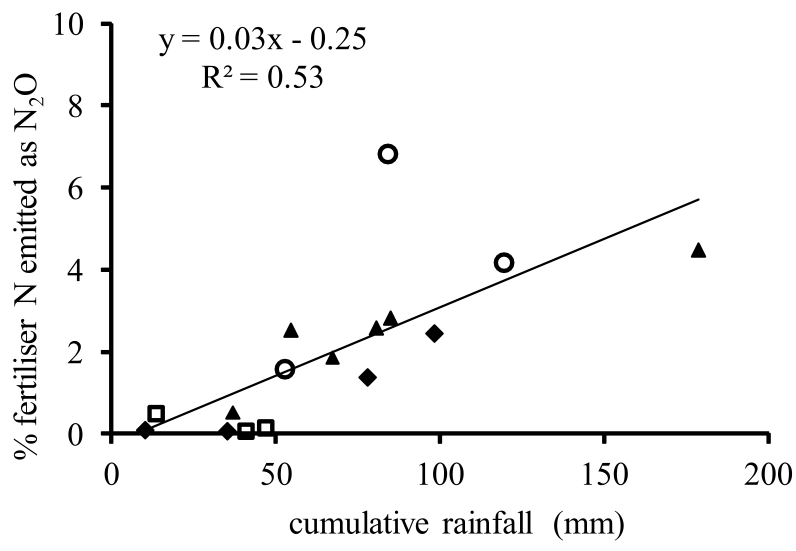

Fig. 4. The role of rainfall in determining $\mathrm{N}_{2} \mathrm{O}$ emission rates after $\mathrm{N}$ fertilisation. Data are average $\mathrm{N}_{2} \mathrm{O}$ fluxes measured in the three weeks after fertilisation (expressed as the percentage of fertiliser $\mathrm{N}$ applied) and the cumulative rainfall in the week before plus three weeks after fertiliser application. Different symbol types represent emission factors in 2007 (circle), 2008 (triangle), 2009 (diamond), and 2010 (square).

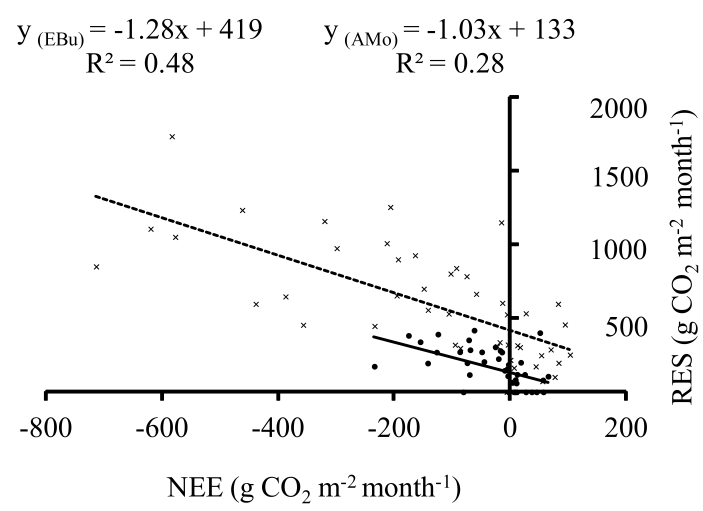

Fig. 5. Relationship between $\mathrm{CO}_{2}$ respiration (RES), measured by chambers enclosing soil and some of the short vegetation, and net ecosystem exchange of $\mathrm{CO}_{2}(\mathrm{NEE})$, measured by eddy covariance at Easter Bush (crosses and dotted trend line) and Auchencorth Moss (black circles and black trend line). Data are monthly sums for 2007 to 2010 .

tended to decrease with increasing soil moisture, but this correlation was not significant.

\subsection{Net ecosystem exchange of carbon dioxide}

Net ecosystem exchange of $\mathrm{CO}_{2}$ followed seasonal cycles (Fig. 1c, d), with $\mathrm{CO}_{2}$ uptake dominating the flux between April and September at both sites. In the cold period (January-March and October-December) $\mathrm{CO}_{2}$ was emitted at very small rates (Fig. 1c, d; Fig. 6) with the exception of the cold period in 2009 at Easter Bush when there was a very small net uptake of $\mathrm{CO}_{2}\left(-17.9 \mathrm{~g} \mathrm{CO}_{2} \mathrm{~m}^{-2} 0.5 \mathrm{yr}^{-1}\right)$. Warm period NEE uptake rates were almost two times larger 


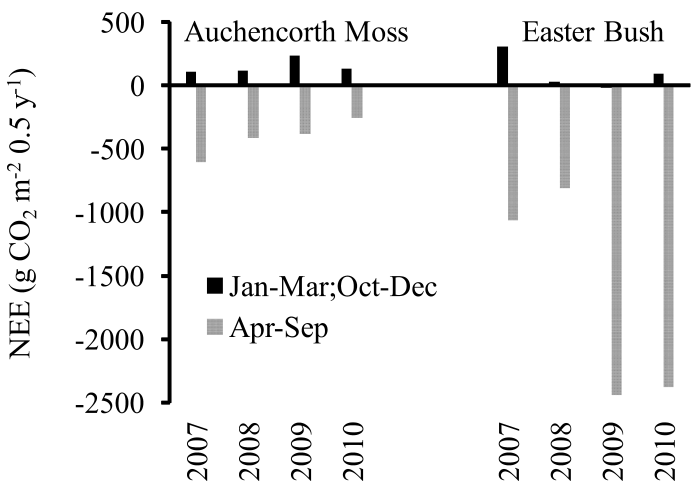

Fig. 6. Cumulative net ecosystem exchange of $\mathrm{CO}_{2}$ (NEE) for the cold period (January-March and October-December) and the warm period (April-September) at Auchencorth Moss and Easter Bush.

at EBu than at AMo in 2007 and 2008; but six and nine times larger in 2009 and 2010, respectively. Annual fluxes ranged from -125 in 2010 to $-498 \mathrm{~g} \mathrm{CO}_{2} \mathrm{~m}^{-2} \mathrm{yr}^{-1}$ in 2007 at AMo and from -758 in 2007 to -2264 in $2010 \mathrm{~g} \mathrm{CO}_{2} \mathrm{~m}^{-2} \mathrm{yr}^{-1}$ at EBu (Table 2).

The NEE of $\mathrm{CO}_{2}$ correlated significantly $(p<0.001)$ with air temperature, PAR, net radiation and total solar radiation. At AMo NEE increased with decreasing water table height $(p<0.01)$, but a significant relationship between NEE and volumetric soil moisture content at $\mathrm{EBu}$ was not observed.

\section{Discussion}

The comparison of the intensively grazed grassland $(\mathrm{EBu})$ with the extensively grazed seminatural moorland (AMo) was conducted to evaluate the effect of land-use and ecosystem on the seasonal and inter-annual patterns of GHG fluxes. At both sites GHG fluxes were dominated by $\mathrm{CO}_{2}$ exchange.

\subsection{Methane and nitrous oxide fluxes}

Methane fluxes at AMo were small compared to those observed in northern peatlands, due to the shallow peat layer and the old drainage system. For example, a recent analysis of $\mathrm{CH}_{4}$ flux measurements made across different soil types and land-uses in the UK showed that AMo $\mathrm{CH}_{4}$ fluxes $\left(37 \mu \mathrm{g} \mathrm{m}^{-2} \mathrm{~h}^{-1}\right)$ were at the top end of the range of $\mathrm{CH}_{4}$ fluxes reported for mineral soils ( 17 to $40 \mu \mathrm{g} \mathrm{m}^{-2} \mathrm{~h}^{-1}$ ), rather than peatlands ( 17 to $1580 \mu \mathrm{g} \mathrm{m}^{-2} \mathrm{~h}^{-1}$ ) (Levy et al., 2012). The largest $\mathrm{CH}_{4}$ fluxes in that analysis were recorded from the deep peats in the flow country (Loch More) (peat depth $=4 \mathrm{~m}$ ), but also from a lowland raised bog, Whim Bog within $2 \mathrm{~km}$ of AMo (peat depth $=6 \mathrm{~m}$ ) (Levy et al., 2012; Carter et al., 2012). Methane fluxes at Loch More and Whim Bog were at least 50 times larger than those at AMo, and were similar to those measured in northern Finland (Drewer et al., 2010; Lohila et al., 2011). This can be explained by the differences in peat depth, which is a key determinant of $\mathrm{CH}_{4}$ fluxes, as discussed by Levy et al. (2012).

An interesting observation is that water table and temperature affected $\mathrm{CH}_{4}$ and $\mathrm{N}_{2} \mathrm{O}$ fluxes in the same manner but only significantly for $\mathrm{CH}_{4}$ (Fig. 3). Both gases were absorbed when the water table was below $0.28 \mathrm{~m}$, and emissions only occurred when the water table was within a few $\mathrm{cm}$ of the surface (above $0.07 \mathrm{~m}$ ). Saturated soils provide the anaerobic conditions required for both methanogenesis and denitrification to operate (Dise et al., 1993; Bakken et al., 2012). In a neutral to slightly acid soil, such as $\mathrm{EBu}$, these conditions would facilitate denitrification to proceed to $\mathrm{N}_{2}$ and one would expect a decline in $\mathrm{N}_{2} \mathrm{O}$ production under water logged conditions. This could not be confirmed, as we did not measure denitrification to $\mathrm{N}_{2}$ at either site. However, in acid soils such as AMo, $\mathrm{N}_{2} \mathrm{O}$ tends to be the end product of denitrification (Bakken et al., 2012).

Soil $\mathrm{CH}_{4}$ fluxes from the intensively grazed grassland $\mathrm{EBu}$ on mineral soil hovered around zero, with small uptake and small emission rates. The occasional larger emissions observed may be due to sheep dropping providing the carbon source and increased anaerobicity during its decomposition to promote methanogenesis.

Nitrous oxide fluxes at Easter Bush showed the typical large spatial and temporal variability common to fertilised grazed grasslands (Jones et al., 2007; Klumpp et al., 2011). In addition to the fertiliser-induced emission peaks, uneven soil compaction and deposition of excreta/urine increased soil heterogeneity even further. Average annual $\mathrm{N}_{2} \mathrm{O}$ fluxes in 2007 and 2008 (Table 2) were similar to those measured from the grazed grass clover field in Ireland (542 $\mathrm{g} \mathrm{CO}_{2} \mathrm{eq} \mathrm{m}^{-2} \mathrm{yr}^{-1}$, Leahy et al., 2004). However, 2009 and 2010 average annual fluxes were much smaller than the Irish measurements, due to lack of rainfall during the fertilisation period (Fig. 4, Table 2). Fertiliser-induced emission rates are not a uniform fraction of the $\mathrm{N}$ applied, as assumed by the Tier 1 IPCC methodology (IPCC, 2006), but depend on rainfall at the time of fertilisation, rate and type of fertiliser, soil and crop type (Cardenas et al., 2010; Ranucci et al., 2011; Klumpp et al., 2011; Flechard et al., 2007). Easter Bush $\mathrm{N}_{2} \mathrm{O}$ emissions calculated as a fraction of mineral $\mathrm{N}$ input were always larger than the IPCC Tier 1 emission factor; they were $6.5 \%, 3.3 \%, 1.4 \%$ and $1.4 \%$ in 2007, 2008, 2009, 2010, respectively. Mineral fertiliser-induced $\mathrm{N}_{2} \mathrm{O}$ emissions are usually short-lived, and background conditions tend to be established within one to three weeks (Fig. 3 and i.e. Bouwman, 1996). The length of the fertiliser-induced peaks depends on the precipitation amount before and during fertilisation. For EBu, cumulative precipitation one week before plus three weeks after fertilisation correlated with the average $\mathrm{N}_{2} \mathrm{O}$ flux during the three weeks after fertilisation better $\left(r^{2}=0.53\right.$, Fig. 4) than when only considering precipitation during the three-week period after fertilisation $\left(r^{2}=0.34\right)$. This simple relationship between $\mathrm{N}_{2} \mathrm{O}$ flux and precipitation is good news for developing Tier 2 emission factors, and 
should be tested for different soil types, crops and climate zones. Fertiliser-induced $\mathrm{N}_{2} \mathrm{O}$ emissions from grasslands are not always larger than the IPCC default value. For example, emission factors ranged from $0.3 \%$ to $0.9 \%$ from fertilised semi-natural grassland in France (Klumpp et al., 2011). In a previous study of GHG fluxes from European grasslands, emission factors ranged from $0.01 \%$ to $3.6 \%$ (Flechard et al., 2007). Their sites covered several climate zones and grassland management types, and explaining variation at this scale required a multilinear regression equation based on changes in soil temperature, soil moisture and rainfall.

\subsection{Carbon dioxide fluxes: respiration and net ecosystem exchange}

The respiration rates reported here are the sum of heterotrophic soil respiration and autotrophic respiration of short vegetation: mosses and small herbs and grasses at AMo and a continuous grass sward at EBu. At EBu respiration measurements included all vegetation present, but at AMo the dominant tall grasses, sedges and heathers could not be included due to the small size of the respiration chamber. Respiration rates increased with increasing air temperature, as also reported by Raich and Schlesinger (1992), but decreased with increasing water table height at AMo and soil moisture at EBu. Jones et al. (2006) reported a bimodal response of soil respiration rates to soil moisture content on a nearby cut grass field on similar soil. When the soil moisture content was below $0.3 \mathrm{~m} \mathrm{~m}^{-3}$, respiration rates increased with increasing moisture; above this rate, soil respiration rates decreased as soils became wetter. The EBu soil moisture contents were usually above $0.3 \mathrm{~m} \mathrm{~m}^{-3}$. Mineral $\mathrm{N}$ fertilisation events did not affect soil respiration rates at $\mathrm{EBu}$, and this agrees with Raich and Schlesinger (1992). The synthesis of Schulze et al. (2010) of carbon flux measurements across Europe (CarboEurope IP) included heterotrophic respiration values for the major land cover types. Heterotrophic soil respiration rates from all CarboEurope grasslands were three times larger than from their peatlands. We calculated very similar values with EBu respiration rates being 2.8 times larger than those at AMo. Respiration rates were five to nineteen times larger than the net ecosystem exchange of $\mathrm{CO}_{2}$ (Table 2), and were not a trivial component of the carbon balance, as also noted by Parkin et al. (2005).

NEE and respiration fluxes for the 2007 to 2010 study period were almost three and six times larger, respectively from the fast growing $\mathrm{N}$ fertilised grass sward at $\mathrm{EBu}$ compared to the slow growing vegetation on the nutrient-poor moorland AMo (Table 2). Similarly, in 2003 and 2004 EBu NEE fluxes were six times larger than fluxes from grazed semi-natural grasslands in France (Laqueuille) and Hungary (Bugać) (Soussanna et al., 2007). The French and Hungarian flux rates of the Soussanna study were of similar magnitude $\left(255 \mathrm{~g} \mathrm{CO}_{2} \mathrm{~m}^{-2} \mathrm{yr}^{-1}\right)$ to those of this paper's AMo data $\left(267 \mathrm{~g} \mathrm{CO}_{2} \mathrm{~m}^{-2} \mathrm{yr}^{-1}\right)$. Easter Bush average annual NEE

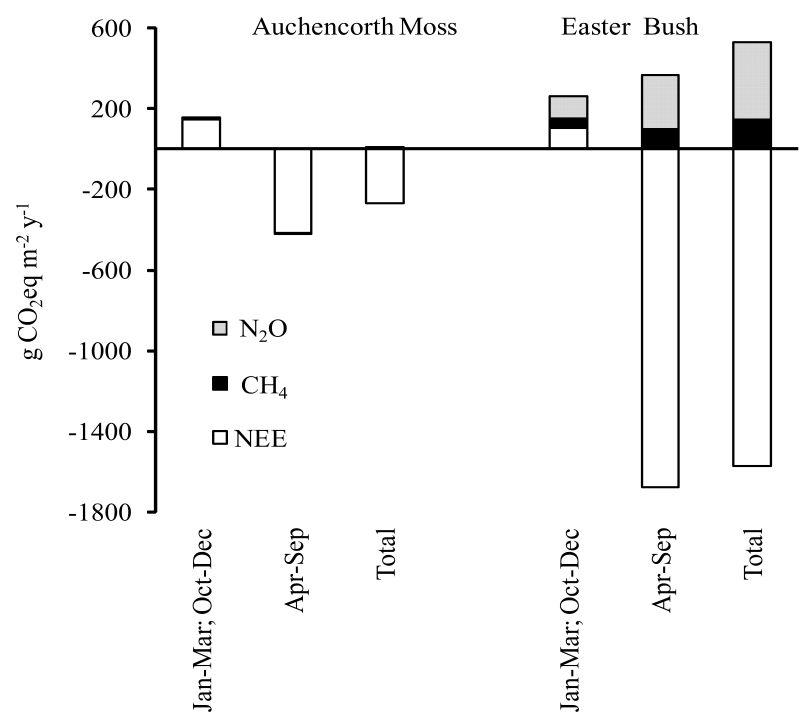

Fig. 7. Greenhouse gas budgets for the semi-natural moorland Auchencorth Moss and the intensively grazed grassland Easter Bush. Data are averages over $4 \mathrm{yr}$ (Total) and split into the period when $\mathrm{NEE} \mathrm{CO}_{2}$ was small or positive (January-March and October-December) and the net ecosystem exchange of $\mathrm{CO}_{2}$ (NEE) uptake period (April-September). At Auchencorth Moss $\mathrm{N}_{2} \mathrm{O}$ fluxes are too small to be visible and the small $\mathrm{CH}_{4}$ fluxes are only visible as a slightly thicker black line.

fluxes in 2007 and $2008\left(771 \mathrm{~g} \mathrm{CO}_{2} \mathrm{~m}^{-2} \mathrm{yr}^{-1}\right)$ were smaller and in 2009 and $2010\left(2363 \mathrm{~g} \mathrm{CO}_{2} \mathrm{~m}^{-2} \mathrm{yr}^{-1}\right)$ larger compared to NEE fluxes measured from two Irish grasslands: a grazed grass clover sward $\left(1074 \mathrm{~g} \mathrm{CO}_{2} \mathrm{~m}^{-2} \mathrm{yr}^{-1}\right.$; Soussana et al., 2007) and a grazed grassland (99\% Lolium) (945 $\mathrm{g} \mathrm{CO}_{2} \mathrm{~m}^{-2} \mathrm{yr}^{-1}$; Leahy et al., 2004).

Substantial differences in $\mathrm{CO}_{2}$ uptake rates were observed during the growing seasons of 2007/2008 and 2009/2010 (Table 2). There is no reason to believe that a systematic bias was introduced between the years 2008 and 2009 as the eddy-covariance measurement system was neither modified nor moved and the analysis routine remained the same. However, environmental and management conditions were slightly different in 2009 and 2010 compared to 2007 and 2008. Total annual rainfall, and that in the warm and cold periods, was lower in 2009 and 2010 compared to 2007 and 2008 (Table 1), but rainfall distribution and number of days with precipitation $<5 \mathrm{~mm}$ during the growing period (April to September) did not change. Air temperature patterns did not differ significantly, but there was a rise in total solar and net radiation (both by $11 \%$ ), PAR $(16 \%)$ and a 17 -fold increase in soil heat flux. Most importantly sheep stocking densities declined over the years and fell to $25 \%$ and $40 \%$ of their 2007 levels for the April to September periods, which correspond approximately to the annual growing season. It is likely that the changes in NEE observed in 2009 and 2010 were caused by the partial removal of a source of $\mathrm{CO}_{2}$ (the 
sheep) rather than a significant change in uptake or the introduction of a methodological bias.

\subsection{Greenhouse gas budgets}

Greenhouse gas budgets were calculated using the 100-yr horizon global warming potential of 25 for $\mathrm{CH}_{4}$ and 298 for $\mathrm{N}_{2} \mathrm{O}$ (IPCC, 2007) (Fig. 7). We only included on-field biological production and consumption processes including livestock $\mathrm{CH}_{4}$ emissions from fermentation. Dengel et al. (2012) measured $\mathrm{CH}_{4}$ emissions by eddy covariance from the herd at EBu between March and October 2010 and calculated a $\mathrm{CH}_{4}$ emission factor of $7.4 \mathrm{~kg} \mathrm{CH}_{4}$ sheep $^{-1} \mathrm{yr}^{-1}$. This measured emission factor is very similar to the IPCC default emission factor of $8 \mathrm{~kg} \mathrm{CH}_{4}$ sheep ${ }^{-1} \mathrm{yr}^{-1}$. Using the measured emission factor, we calculated that sheep contributed a further $147 \mathrm{~g} \mathrm{CO}_{2 \mathrm{eq}} \mathrm{m}^{-2} \mathrm{yr}^{-1}$ to the average annual GHG budget at $\mathrm{EBu}$ and less than $0.01 \mathrm{~g} \mathrm{CO}_{2 \mathrm{eq}} \mathrm{m}^{-2} \mathrm{yr}^{-1}$ at AMo.

$\mathrm{NEE}$ of $\mathrm{CO}_{2}$ provided the largest term in the annual GHG budgets at Auchencorth Moss and Easter Bush (Table 2). At AMo $\mathrm{CH}_{4}$ and $\mathrm{N}_{2} \mathrm{O}$ emissions counteracted the NEE sink strength by $2.8 \%$ and $0.3 \%$, respectively, and the average 4-yr GHG budget thus was $-260 \mathrm{~g} \mathrm{CO}_{2 \mathrm{eq}} \mathrm{m}^{-2} \mathrm{yr}^{-1}$. Interannual variations (Table 2) were mainly caused by variations in NEE during the growing period, April to September (Fig. 6). In contrast, fertiliser use and sheep grazing significantly impacted the NEE sink at EBu. Fertiliser-induced $\mathrm{N}_{2} \mathrm{O}$ emissions reduced the NEE sink strength by $25 \%$ and ruminant $\mathrm{CH}_{4}$ emissions by $10 \%$. The 4 -yr-average GHG budget was $-1034 \mathrm{~g} \mathrm{CO}_{2 \mathrm{eq}} \mathrm{m}^{-2} \mathrm{yr}^{-1}$, and thus almost four times larger than at AMo. Inter-annual variations were mainly influenced by variations in NEE during the growing period and variations in $\mathrm{N}_{2} \mathrm{O}$ due to variations in precipitation at times of fertiliser application. In 2007 and 2008 large $\mathrm{N}_{2} \mathrm{O}$ emissions, large sheep populations, hence large ruminant $\mathrm{CH}_{4}$ fluxes, negated all or most of the $\mathrm{CO}_{2}$ uptake. Similar observations were made by Leahy et al. (2004).

\section{Conclusions}

The GHG budget of a drained acid moorland (Auchencorth Moss) was found to be dominated by net ecosystem exchange of $\mathrm{CO}_{2} ; \mathrm{CH}_{4}$ and $\mathrm{N}_{2} \mathrm{O}$ fluxes were insignificant by comparison and were only emitted when the water table was close to the surface. For an intensively grazed fertilised grassland (Easter Bush), $\mathrm{CO}_{2}, \mathrm{CH}_{4}$ and $\mathrm{N}_{2} \mathrm{O}$ contributed significantly to the overall GHG balance. Precipitation before and during fertilisation periods correlated with $\mathrm{N}_{2} \mathrm{O}$ emissions. Frequent rainfall events, as commonly experienced in NW Europe, together with a high ruminant stocking density can significantly reduce the GHG sink or turn the sink into a source, as seen here for 2007 at Easter Bush. High productivity facilitated by fertilisation resulted in much larger $\mathrm{CO}_{2}$ uptake rates on the grassland during the growing season than on the acid moorland. However, this positive effect of $\mathrm{CO}_{2}$ uptake was greatly reduced by large $\mathrm{CH}_{4}$ and $\mathrm{N}_{2} \mathrm{O}$ emissions.

Acknowledgements. We wish to thank the EU for supporting this work through the NitroEurope IP and national bodies, including the UK National Environment Research Council and the UK Department for Environment, Food and Rural Affairs and landowners for access to Auchencorth Moss and Easter Bush; and the Biogeochemical Model-Data Integration Group at Max Planck Institute for Biogeochemistry in Jena, Germany, for the online partitioning tool.

Edited by: A. R. Mosier

\section{References}

Bakken, L. R., Bergaust, L., Liu, B., and Frostegard, A.: Regulation of denitrification at the cellular level: a clue to the understanding of $\mathrm{N}_{2} \mathrm{O}$ emissions from soil, Philos. T. R. Soc. B., 367, 12261234, 2012.

Bouwman, A. F.: Direct emission of nitrous oxide from agricultural soils, Nutr. Cycl. Agroecosys., 46, 53-70, 1996.

Cardenas, L. M., Thorman, R., Ashlee, N., Butler, M., Chadwick, D., Chambers, B., Cuttle, S., Donovan, N., Kingston, H., Lane, S., Dhanoa, M. S., and Scholefield, D.: Quantifying annual $\mathrm{N}_{2} \mathrm{O}$ emission fluxes from grazed grassland under a range of inorganic fertiliser nitrogen inputs. Agr. Ecosyst. Environ., 136, 218-226, 2010.

Carter, M. S., Larsen, K. S., Emmett, B., Estiarte, M., Field, C., Leith, I. D., Lund, M., Meijide, A., Mills, R. T. E., Niinemets, Ü., Peñuelas, J., Portillo-Estrada, M., Schmidt, I. K., Selsted, M. B., Sheppard, L. J., Sowerby, A., Tietema, A., and Beier, C.: Synthesizing greenhouse gas fluxes across nine European peatlands and shrublands - responses to climatic and environmental changes, Biogeosciences, 9, 3739-3755, doi:10.5194/bg-93739-2012, 2012.

Clayton, H., Arah, J. R. M., and Smith, K. A.: Measurement of nitrous oxide emissions from fertilised grassland using closed chamber, J. Geophys. Res., 99, 16599-16607, 1994.

Dengel, S., Levy, P., Grace, J., Jones, S. K., and Skiba, U. M.: Methane emissions from sheep pasture, measured with an openpath eddy covariance system, Global Change Biol., 17, 35243533, 2011.

Dinsmore, K. J.: Atmosphere-Soil-Stream Greenhouse GS Fluxes from Peatland, PhD Thesis, University of Edinburgh, UK, 2008.

Dinsmore, K. J., Skiba, U. M., Billett, M. F., Rees, R. M., and Drewer, J.: Spatial and temporal variability in $\mathrm{CH}_{4}$ and $\mathrm{N}_{2} \mathrm{O}$ fluxes from a Scottish ombrotrophic peatland; implications for modelling and upscaling, Soil Biol. Biochem., 41, 1315-1323, 2009.

Dise, N. B., Gorham, E., and Verry E. S.: Environmental-factors controlling methane emissions from peatlands in Northern Minnesota, J. Geophys. Res., 98, 10583-10594, 1993.

Drewer, J., Lohila, A., Aurela, M., Laurila, T., Minkkinen, K., Penttilä, T., Dinsmore, K. J., McKenzie, R., Helfter, C., Flechard, C., Sutton, M. A., and Skiba, U. M.: Comparison of greenhouse gas fluxes and nitrogen budgets from an ombotrophic bog in Scot- 
land and a pristine mire in Finland, Eur. J. Soil Sci., 61, 640-650, 2010.

Flechard, C. R., Ambus, P., Skiba, U. M., Rees, R. M., Hensen, A., van Amstel, A., van den Pol-van Dasselaar, A., Soussana, J.F., Jones, M., Clifton-Brown, J., Raschi, A., Horvath, L., Neftel, A., Jocher, M., Ammann, C., Leifeld, J., Fuhrer, J.,Calanca, P., Thalman, E., Pilegaard, K., Di Marco, C., Campbell, C., Nemitz, E.,Hargreaves, K. J., Levy, P., Ball, B. C., Jones, S., van de Bulk, W. C. M., Groot, T., Blom, M., Domingues, R., Kasper, G., Allard, V., Jolivot, D., Cellier, P., Laville, P., Henault, C., Bizouard, F., Abdalla, M., Williams, M., Baronti, S., Berretti, F., and Grosz, B.: Effects of climate and management intensity on nitrous oxide emissions in grassland systems across Europe, Agr. Ecosys. Environ., 121, 135-52, 2007.

Foken, T. and Wichura, B.: Tools for quality assessment of surfacebased flux measurements, Agr. Forest Meteorol., 78, 83-105, 1996.

Foken, T., Gödecke, M., Mauder, M., Mahrt, L., Amiro, B., and Munger, W.: Post-field data quality control, in: Handbook of micrometeorology, edited by: Lee, X., Kluwer Academic Publishers, 2004.

IPCC 2006: IPCC Guidelines for National Greenhouse Gas Inventories; Prepared by the National Greenhouse Gas Inventories Programme, Japan, IPCC, 2006.

IPCC 2007: Climate Change (2007): The Physical Science Basis, Technical summary, in: Contribution of Working Group 1 to the Forth Assessment Report of the Intergovernmental Panel on Climate Change, edited by: Solomon, S., Qin, D., Manning, M., Chen, Z., Marquis, M., Averyt, K. B., Tignor, M., and Miller, H. L., Cambridge University Press, Cambridge, UK, 2007.

Jones, S. K., Rees, R. M., Kosmas, D., Ball, B. C., and Skiba, U. M.: Carbon sequestration in a temperate grassland; management and climatic controls, Soil Use Manage., 22, 132-142, 2006.

Jones, S. K., Rees, R. M., Skiba, U. M., and Ball, B. C.: Influence of organic and mineral $\mathrm{N}$ fertiliser on $\mathrm{N}_{2} \mathrm{O}$ fluxes from a temperate grassland, Agr. Ecosys. Environ., 121, 74-83, 2007.

Jones, S. K., Famulari, D., Di Marco, C. F., Nemitz, E., Skiba, U. M., Rees, R. M., and Sutton, M. A.: Nitrous oxide emissions from managed grassland: a comparison of eddy covariance and static chamber measurements, Atmos. Meas. Tech., 4, 2179 2194, doi:10.5194/amt-4-2179-2011, 2011.

Klumpp, K., Bloor, J. M. G., Ambus, P., and Soussana, J.-F.: Effects of clover density on $\mathrm{N}_{2} \mathrm{O}$ emissions and plant-soil $\mathrm{N}$ transfers in a fertilised upland pasture, Plant Soil, 343, 97-107, 2011.

Leahy, P., Kiely, G., and Scanlon, T. M.: Managed grasslands: A greenhouse gas sink or source?, Geophys. Res. Lett., 31, L20507 doi:10.1029/2004GL021161, 2004.

Levy, P. E., Burden, A., Cooper, M. D. A., Dinsmore, K. J., Drewer, J., Evans, C., Fowler, D., Gaiawyn, J., Gray, A., Jones, S. K., Jones, T., McNamara, N. P., Mills, R., Ostle, N., Sheppard, L. J., Skiba, U., Sowerby, A., Ward, S. E., and Zielinski, P.: Methane emissions from soils: synthesis and analysis of a large UK data set, Global Change Biol., 18, 1657-1669, 2012.

Lohila, A., Aurela, M., Hatakka, J., Minkkinen, K., Pihlatie, M., Penttilea, T., and Laurila, T.: Responses of $\mathrm{N}_{2} \mathrm{O}$ fluxes to temperature, water table and $\mathrm{N}$ deposition in a northern boreal fen, Eur. J. Soil Sci., 61, 651-661, 2011.

MacDonald, J. A., Skiba, U., Sheppard, L. J., Hargreaves, K. J., Smith, K. A., and Fowler, D.: Soil environmental variables af- fecting the flux of methane from a range of forest, moorland and agricultural soils, Biogeochemistry, 34, 113-132, 1996.

Parkin, T. B., Kaspar, T. C., Senwo, Z., Prueger, J. H., and Hatfield, J. L.: Relationship of soil respiration to crop and landscape in the Walnut Creek watershed, J. Hydrometeorol., 6, 312-324, 2005.

Raich, J. W. and Schlesinger, W. H.: The global carbon dioxide flux in soil respiration and its relationship to vegetation and climate, Tellus B, 44, 81-99, 1992.

Ranucci, S., Bertolini, T., Vitale, L., Di Tommasi, P., Ottaiano, L., Oliva, M., Amato, U., Fierro, A., and Magliulo, V.: The influence of management and environmental variables on soil $\mathrm{N}_{2} \mathrm{O}$ emissions in a crop system in Southern Italy, Plant Soil, 343, 83-96, 2011.

Reichstein, M., Falge, E., Baldocchi, D., Papale, D., Aubinet, M., Berbigier, P., Bernhoffer, C., Buchmann, N., Gilmanov, T., Granier, A., Grünwald, T., Havránková, K., Ilvesniemi, H., Dalibor, J., Knohl, A., Laurila, T., Lohila, A., Loustau, D., Matteucci, G., Meyers, T., Miglietta, F., Ourcival, J.-M., Pumpanen, J., Rambal, S., Rotenberg, E., Sanz, M., Tenhunen, J., Seufert, G., Vaccari, F., Vesala, T., Yakir, D., and Valenitni, R.: On the separation of net ecosystem exchange into assimilation and ecosystem respiration: review and improved algorithm, Global Change Biol., 11, 1424-1439, 2005.

Schulze, E. D., Ciais, P., Luyssaert, S., Schrumpf, M., Janssens, I. A., Thiruchittampalam, B., Theloke, J., Saurat, M., Bringezu, S. Lelieveld, J., Lohila, A., Rebmann, C., Jung, M., Bastviken, D., Abril, G., Grassi, G., Leip, A., Freibauer, A., Kutsch, W., Don, A., Nieschulze, J., Börner, A., Gash, J. H., and Dolman, A. J.: The European carbon balance. Part 4: integration of carbon and other trace-gases fluxes, Global Change Biol., 16, 1451-1469, 2010.

Skiba, U., Drewer, J., Tang, Y. S., van Dijk, N., Helfter, C., Nemitz, E., Famulari, D., Cape, J. N., Jones, S. K., Twigg, M., Pihlatie, M., Vesala, T., Larsen, K. S., Carter, M. S., Ambus, P., Ibrom, A., Beier, C., Hensen, A., Frumau, A., Erisman, J. W., Brüggemann, N.,Gasche, R., Butterbach-Bahl, K., Neftel, A., Spirig, C., Horvath, L., Freibauer, A., Cellier, P., Laville, P., Loubet , B., Magliulo, E., Bertolini, T., Seufert, G., Andersson, M., Manca, G., Laurila, T., Aurela, M., Lohila A., Zechmeister-Boltenstern, S., Kitzler, B., Schaufler, G., Siemens, J., Kindler, R., Flechard, C., and Sutton, M. A.: Biosphere atmosphere exchange of reactive nitrogen and greenhouse gases at the NitroEurope core flux measurement sites: Measurement strategy and first annual data set, Agr. Ecosys. Environ., 133, 139-149, 2009.

Soussana, J.-F., Allard, V., Pilegaard, K., Ambus, P., Amman, C., Campbell, C., Ceschia, E., Clifton-Brown, J., Czobel, S., Domingues, R., Flechard, C., Fuhrer, J., Hensen, A., Horvath, L., Jones, M., Kasper, G., Martin, C., Nagy, Z., Neftel, A., Raschi, A., Baronti, S., Rees, R. M., Skiba, U., Stefani, P., Manca, G., Sutton, M., Tuba, Z., and Valentini, R..: Full accounting of the greenhouse gas $\left(\mathrm{CO}_{2}, \mathrm{~N}_{2} \mathrm{O}, \mathrm{CH}_{4}\right)$ budget of nine European grassland sites, Agr. Ecosys. Environ., 121, 121-134, 2007.

Sutton, M. A., Milford, C., Nemitz, E., Theobald, M. R., Hill, P. W., Fowler, D., Schjoerring, J. K., Mattsson, M. E., Nielsen, K. H., and Husted, S.: Biosphere-atmosphere interactions of ammonia with grasslands: Experimental strategy and results from a new European initiative, Plant Soil, 228, 131-145, 2001. 